\title{
Pengelompokan Potensi Produksi Buah-Buahan di Provinsi Sumatera Utara dengan Menerapkan K-Clustering (Studi Kasus : Dinas Tanaman Pangan dan Holtikultura)
}

\author{
Herna Mahulae \\ Program Studi Teknik Informatika, STMIK Budi Darma, Medan, Indonesia \\ Email: Hyerna27@gmail.com \\ Submitted 16-04-2020; Accepted 25-04-2020; Published 26-04-2020
}

\begin{abstract}
Abstrak
Hingga saat ini sektor pertanian masih memegang peranan penting dalam perekonomian nasional. Buah-buahan merupakan komoditas komersial yang sangat strategis untuk dikembangkan dan diperdagangkan baik di pasar daerah, nasional maupun internasional. Sehingga kondisi yang optimal pada suatu daerah untuk produksi komoditas jenis buah-buahan merupakan keunggulan komparatif yang sangat penting. Berdasarkan data hasil produksi buah di Dinas Tanaman Pangan Dan Hortikultura Sumatera Utara menampilkan beberapa daerah dengan hasil panen buahyang bervariasi jumlahnya. Untuk itu diperlukan pengelompokan daerah potensial penghasil buah untuk berdasarkan nama-nama kabupaten/kota yang sangat berpotensi sebagai penghasil buah. Dengan menggunakan Metode K-Means Clustering, pembagian kelompok daerah dapat dilakukan berdasarkan luas panen (Ha), produksi(ton) dan tahun panen. Pada penelitian ini dilakukan pengklasteran daerah potensial penghasil buah menggunakan algoritma K-Means. Dengan menggunakan K-Means bertujuan dalam memudahkan pengelompokan suatu daerah dalam mengetahui tingkat potensi berdasarkan kabupaten/kota di provinsi sumatera utara.
\end{abstract}

Kata Kunci: Data Mining, Algoritma K-Means Clustering, Pengelompokan Produksi Buah-Buahan.

\begin{abstract}
Until now the agricultural sector still plays an important role in the national economy. Fruits are commercial commodities which are very strategic to be developed and traded in regional, national and international markets. So that the optimal conditions in an area for the production of commodity types of fruit is a very important comparative advantage. Based on data on fruit production results in the Office of Food and Horticultural Crops of North Sumatra showing several regions with varying amounts of fruit yields. For this reason, grouping of potential fruit-producing regions is needed to be based on the names of districts / cities that have the potential to produce fruit. By using the K-Means Clustering Method, the division of regional groups can be done based on the harvested area (Ha), production (tons) and the year of harvest. In this research, clustering of fruit-producing potential areas was carried out using the K-Means algorithm. By using KMeans aims to facilitate the grouping of an area in knowing the level of potential based on districts / cities in the province of North Sumatra.
\end{abstract}

Keywords: Data Mining, K-Means Clustering Algorithm, Grouping of Fruit Production.

\section{PENDAHULUAN}

Buah-buahan merupakan salah satu komoditas holtikultura yang memegang peranan penting bagi pembangunan pertanian di Indonesia. Fungsi buah-buahan sangat penting bagi proses metabolisme tubuh karena mengandung vitamin, mineral, protein dan serat. indonesia adalah salah satu negara penghasil buah tropis yang memiliki keanekaragaman dan keunggulan cita rasa yang cukup baik bila dibandingkan dengan buah-buahan dari negara-negara penghasil buah tropis lainnya. hal ini berarti bahwa buah-buahan memiliki prospek yang cerah untuk dikembangkan.

Sumatera Utara merupakan salah satu provinsi penghasil buah terbesar di Indonesia. Meskipun demikian muncul permasalahan yaitu kurang meratanya produksi ditiap kabupaten/kota sehingga produksi buah menjadi tidak optimal. Hal inilah yang menjadi konsen utama dari Dinas Tanaman Pangan dan Holtikultura untuk segera mengatasi permasalahan yang terjadi. Hal yang dapat dilakukan adalah dengan mengelompokan tingkat produksi buah secara rinci berdasarkan kabupaten dan kota. Hal ini dilakukan agar pihak Dinas Tanaman Pangan dan Holtikultura dapat menetukan daerah-daerah mana saja yang tingkat produksi buahnya masih kurang sehingga dapat diambil kebijakan yang tepat dan akurat.

Metode K-Clustering adalah proses pengelompokan kumpulan data menjadi beberapa kelompok sehingga objek di dalam satu kelompok memiliki banyak persamaan dan memiliki banyak perbedaan dengan objek di kelompok lain [1]. Perbedaan dan persamaannya biasanya nilai atribut dari objek tersebut dan dapat juga berupa perhitungan jarak. Dalam masalah yang dibahas pada penelitian ini diharapkan menjadi solusi pemecahan masalah. Diharapkan pada akhir penelitian ini didapatkan sebuah kesimpulan yang berisi pengelompokan daerah-daerah yang memiliki tingkat produksi buah yang tinggi ataupun tingkat produksi buah yang masih rendah.

\section{METODE PENELITIAN}

\subsection{Data Mining}

Data Mining adalah proses yang menggunakan teknik statistik, matematika, kecerdasan buatan, dan machine learning untuk mengekstraksi dan mengidentifikasi informasi yang bermanfaat dan pengetahuan yang terkait dari berbagai database besar'[2]. Jadi dapat disimpulkan bahwa Data Mining adalah serangkaian proses untuk menggali nilai tambah berupa informasi yang selama ini tidak diketahui secara manual dari suatu basis data. Informasi yang dihasilkan diperoleh dengan cara mengekstraksi dan mengenali pola yang penting atau menarik dari data yang terdapat dalam basis data. 


\subsection{Metode K-means}

Metode K-means merupakan metode clustering yang paling sederhana dan umum. Hal ini dikarenakan K-means mempunyai kemampuan mengelompokkan data dalam jumlah yang cukup besar dengan waktu komputasi yang cepat dan efisien. $K$-Means merupakan salah satu algoritma klustering dengan metode partisi (partitioning method) yang berbasis titik pusat (centroid) selain algoritma $k$-Medoids yang berbasis obyek[3].

Algoritma $k$-Means dalam penerapannya memerlukan tiga parameter yang seluruhnya ditentukan pengguna yaitu jumlah cluster $k$, inisialisasi klaster, dan jarak system, Biasanya, $k$-Means dijalankan secara independen dengan inisialisasi yang berbeda menghasilkancluster akhir yang berbeda karena algoritma ini secara prinsip hanya mengelompokan data menuju local minimal. Salah satu cara untuk mengatasi localminima adalah dengan mengimplementasikan algoritma $k$ Means, untuk K yang diberikan, dengan beberapa nilai initial partisi yang berbeda dan selanjutnya dipilih partisi dengan kesalahan kuadrat terkecil

Dalam penerapan algoritma $k$-Means, jika diberikan sekumpulan data $X=\left\{\mathrm{x}_{1}, \mathrm{x}_{2}, \ldots, \mathrm{x}_{\mathrm{n}}\right\}$ dimana $\mathrm{xi}=\left(\mathrm{x}_{\mathrm{i} 1}, \mathrm{x}_{\mathrm{i} 2}, \ldots\right.$, $\mathrm{x}_{\text {in }}$ ) adalah system dalam ruang real $R n$, maka algoritma $k$-Means akan menyusun partisi $X$ dalam sejumlah $k$ cluster (a priori). Setiap cluster memiliki titik tengah (centroid) yang merupakan nilai rata rata (mean) dari data-data dalam cluster tersebut. Tahapan awal, algoritma $k$-Means adalah memilih secara acak $k$ buah obyek sebagai centroid dalam data. Kemudian, jarak antara obyek dan centroid dihitung menggunakan Euclidiandistance. Algoritma $k$-Means secara iterative meningkatkan variasi nilai dalam dalam tiap tiap cluster dimana obyek selanjutnya ditempatkan dalam kelompok yang terdekat, dihitung dari titik tengah klaster. Titik tengah baru ditentukan bila semua data telah ditempatkan dalam cluster terdekat. Proses penentuan titik tengah dan penempatan data dalam cluster diulangi sampai nilai titik tengah dari semua cluster yang terbentuk tidak berubah lagi [4]vfv. Tahap ini dilakukan penerapan algorima $k$-means dengan rumus

$$
D_{e}=\sqrt{(x i-s i)^{2}+(y i-t i)^{2}}
$$

Proses clustering dengan menggunakan algoritma k-Means memiliki langkah-langkah sebagai berikut :

1. Inisialiasi: Tentukan $\mathrm{K}$ sebagai jumlah cluster yang diinginkan dan metrik ketidakmiripan (jarak) yang diinginkan.

2. Pilih $\mathrm{K}$ data baru set data $\mathrm{X}$ sebagai centeroid terdekat,

3. Alokasikan semua data ke centeroid terdekat dengan metrik yang sudah ditetapkan (memperbaharui ID setiap data)

4. Hitung kembali centeroid $\mathrm{C}$ berdasarkan data yang mengikuti c;uster masing-masing.

5. Ulangi langkah tiga empat hingga kondisi konvergen tercapai, yaitu (a) perubahan fungsi objektif sudah dibawah lambang batas yang diinginkan: atau (b) tidak ada data yang berpindah cluster: atau (c) perubahan posisi centeroid sudah dibawah ambang batas yang ditetapkan.

\section{HASIL DAN PEMBAHASAN}

Analisa permasalahan merupakan suatu tahapan yang dilakukan untuk mengetahui permasalahan-permasalahan yang terjadi dan mencari solusi dari pemecahan masalah seputar pengelompokan potensi produksi buah di Provinsi Sumatera Utara. Analisa permasalahan dilakukan dengan tehnik wawancara dan pengumpulan data di kantor Dinas Tanaman Pangan dan Holtikultura Provinsi Sumatera Utara. Setelah melakukan wawancara dan peninjauan dokumen pada Dinas Tanaman Pangan dan Holtikultura Provinsi Sumatera Utara, tahapan selanjutnya yaitu menggambarkan sistem yang akan dirancang ke dalam bentuk diagram alir, maupun bentuk Unified Modeling Language (UML). Dari hasil penggambaran tersebut dapat terlihat apa saja yang dibutuhkan untuk pengembangan sistem agar sistem yang dirancang berjalan sempurna sesuai yang diinginkan.

Pada bab ini akan dijelaskan mengenai analisis dan perancangan dalam menerapkan sistem Data Mining yang mengadopsi metode K-Clustering. Analisis ini meliputi tentang penentuan penyeleksian sampel data berdasarkan beberapa kriteria yang didapat dari data Dinas Tanaman Pangan dan Holtikultura Provinsi Sumatera Utara, pembersihan data dan transformasi data yang dilakukan dengan cara menormalisasi data agar dapat diproses sistem dengan menggunakan metode K-Clustering. Nilai yang diinputkan merupakan data dari Dinas Tanaman Pangan dan Holtikultura Provinsi Sumatera Utara berupa data Kabupaten/Kota, Data Produksi buah alpukat, belimbing dan duku yang nantinya akan diolah dengan menggunakan rumus pada K-Clustering.

Berikut ini merupakan data yang dipakai didalam penelitian ini. Data ini berasal dari Dinas Tanaman Pangan dan Holtikultura Provinsi Sumatera Utara :

Tabel 1. Data Produksi Buah-buahan Prov. Sumatera Utara2017

\begin{tabular}{llrrr}
\hline No & Kabupaten/Kota & $\begin{array}{c}\text { Plpukat } \\
\mathbf{2 0 1 7}\end{array}$ & $\begin{array}{c}\text { Produksi Buah } \\
\text { Belimbing } \\
\mathbf{2 0 1 7}\end{array}$ & \multicolumn{1}{c}{$\begin{array}{c}\text { Duku } \\
\mathbf{2 0 1 7}\end{array}$} \\
\hline 1 & Nias & 1,3 & 2,7 & 148 \\
2 & Madina & 129,1 & 293,3 & 747,7 \\
3 & Tap. Selatan & 2899,7 & 196 & 1133,7 \\
4 & Tap. Tengah & 22,3 & 3,1 & 667,8 \\
5 & Tap. Utara & 3726,9 & 168,6 & 1374,3 \\
\hline
\end{tabular}




\begin{tabular}{clrrr}
\hline 6 & Toba Samosir & 226 & 2,7 & 1,5 \\
7 & Lab. Batu & 2,4 & 42,6 & 121,6 \\
8 & Asahan & 237,4 & 223,5 & 270 \\
9 & Simalungun & 1233,1 & 38,2 & 391,2 \\
10 & Dairi & 1647,8 & 0 & 1089,2 \\
11 & Karo & 2322,5 & 3,1 & 357,1 \\
12 & D. Serdang & 190,9 & 2160,8 & 3158,6 \\
13 & Langkat & 109,3 & 350,4 & 939 \\
14 & Nias Selatan & 10,8 & 9,8 & 77,2 \\
15 & H. Hasundatan & 425,8 & 0 & 544,9 \\
16 & Pakpak Bharat & 152,7 & 0 & 0 \\
17 & Samosir & 1299,2 & 0 & 0 \\
18 & Serdang Bedagai & 54,9 & 54,6 & 354,2 \\
19 & Batu Bara & 4,6 & 2,2 & 0 \\
20 & Paluta & 0 & 0 & 0 \\
21 & Padang Lawas & 8,4 & 11,7 & 1447,5 \\
22 & Labusel & 11,9 & 9 & 7,6 \\
23 & Labura & 0 & 0 & 0 \\
24 & Nias Utara & 0 & 1 & 4,8 \\
25 & Nias Barat & 0,2 & 2,8 & 32,3 \\
26 & Tj. Balai & 0,5 & 11,3 & 0 \\
27 & P. Siantar & 19,2 & 3,9 & 0 \\
28 & Tebing Tinggi & 46,4 & 24 & 4,5 \\
29 & Medan & 147,6 & 157,7 & 3,6 \\
30 & Binjai & 64,1 & 47,9 & 44,1 \\
31 & P. Sidempuan & 52,2 & 30,1 & 35,2 \\
32 & Gn. Sitoli & 44 & 38,2 & 80,5 \\
& Jumlah & $\mathbf{1 5 0 9 1}$ & & $\mathbf{1 3 0 3 6}$ \\
\hline
\end{tabular}

Berikut ini merupakan langkah-langkah yang dilakukan untuk menyelesaikan permasalahan pada data yang diperoleh.

1. Langkah pertama yang dilakukan untuk menyelesaikan perhitungan ini adalah memilih jumlah cluster $\mathrm{K}$. Cluster $\mathrm{K}$ dari sumber data Tabel 2. adalah alpukat, belimbing dan duku pada periode data di tahun 2017.

Tabel 2. Cluster K

\begin{tabular}{clrrr}
\hline No & Kabupaten/Kota & V1 & V2 & V3 \\
\hline 1 & Nias & 1,3 & 2,7 & 148 \\
2 & Madina & 129,1 & 293,3 & 747,7 \\
3 & Tap. Selatan & 2899,7 & 196 & 1133,7 \\
4 & Tap. Tengah & 22,3 & 3,1 & 667,8 \\
5 & Tap. Utara & 3726,9 & 168,6 & 1374,3 \\
6 & Toba Samosir & 226 & 2,7 & 1,5 \\
7 & Lab. Batu & 2,4 & 42,6 & 121,6 \\
8 & Asahan & 237,4 & 223,5 & 270 \\
9 & Simalungun & 1233,1 & 38,2 & 391,2 \\
10 & Dairi & 1647,8 & 0 & 1089,2 \\
11 & Karo & 2322,5 & 3,1 & 357,1 \\
12 & D. Serdang & 190,9 & 2160,8 & 3158,6 \\
13 & Langkat & 109,3 & 350,4 & 939 \\
14 & Nias Selatan & 10,8 & 9,8 & 77,2 \\
15 & H. Hasundatan & 425,8 & 0 & 544,9 \\
16 & Pakpak Bharat & 152,7 & 0 & 0 \\
17 & Samosir & 1299,2 & 0 & 0 \\
18 & Serdang Bedagai & 54,9 & 54,6 & 354,2 \\
19 & Batu Bara & 4,6 & 2,2 & 0 \\
20 & Paluta & 0 & 0 & 0 \\
21 & Padang Lawas & 8,4 & 11,7 & 1447,5 \\
22 & Labusel & 11,9 & 9 & 7,6 \\
23 & Labura & 0 & 0 & 0 \\
24 & Nias Utara & 0 & 1 & 4,8 \\
25 & Nias Barat & 0,2 & 2,8 & 32,3 \\
26 & Tj. Balai & 0,5 & 11,3 & 0 \\
\hline & & & & \\
\hline
\end{tabular}


Dimana

\begin{tabular}{llrrr}
\hline 27 & P. Siantar & 19,2 & 3,9 & 0 \\
28 & Tebing Tinggi & 46,4 & 24 & 4,5 \\
29 & Medan & 147,6 & 157,7 & 3,6 \\
30 & Binjai & 64,1 & 47,9 & 44,1 \\
31 & P. Sidempuan & 52,2 & 30,1 & 35,2 \\
32 & Gn. Sitoli & 44 & 38,2 & 80,5 \\
& Jumlah & $\mathbf{1 5 0 9 1}$ & $\mathbf{3 8 8 9 , 2}$ & $\mathbf{1 3 0 3 6}$ \\
\hline
\end{tabular}

V1 : Alpukat

V2 : Belimbing

V3 : Duku

Selanjutnya yaitu melakukan inisialisasi atau asumsi K pusat cluster. Asumsi ini bertujuan untuk mempermudah perhitungan. Berikut ini merupakan tabel untuk asumsi jumlah produksi buah :

Tabel 3. Asumsi Nilai Produksi Buah-buahan

\begin{tabular}{cc}
\hline Jumlah Produksi & Asumsi \\
\hline $0-199$ ton & 1 \\
$200-399$ ton & 2 \\
$400-599$ ton & 3 \\
$600-799$ ton & 4 \\
$800-999$ ton & 5 \\
$1000-1199$ ton & 6 \\
$1200-1399$ ton & 7 \\
$1400-1599$ ton & 8 \\
$1600-1799$ ton & 9 \\
$1800-1999$ ton & 10 \\
$2000-2199$ ton & 11 \\
$2200-2399$ ton & 12 \\
$2400-2599$ ton & 13 \\
$2600-2799$ ton & 14 \\
$2800-2999$ ton & 15 \\
$3000-5000$ ton & 16 \\
\hline
\end{tabular}

Setelah melakukan proses inisialisasi terhadap data yang diperoleh. Berikut ini merupakan tabel hasil inisialisasi terhadap tabel 4:

Tabel 4. Hasil inisialisasi

\begin{tabular}{clccc}
\hline No & Kabupaten/Kota & X1 & X2 & X3 \\
\hline 1 & Nias & 1 & 1 & 1 \\
2 & Madina & 1 & 2 & 4 \\
3 & Tap. Selatan & 15 & 1 & 6 \\
4 & Tap. Tengah & 1 & 1 & 4 \\
5 & Tap. Utara & 16 & 1 & 7 \\
6 & Toba Samosir & 2 & 1 & 1 \\
7 & Lab. Batu & 1 & 1 & 1 \\
8 & Asahan & 2 & 2 & 2 \\
9 & Simalungun & 7 & 1 & 2 \\
10 & Dairi & 9 & 1 & 6 \\
11 & Karo & 12 & 1 & 2 \\
12 & D. Serdang & 1 & 11 & 16 \\
13 & Langkat & 1 & 2 & 5 \\
14 & Nias Selatan & 1 & 1 & 1 \\
15 & H. Hasundatan & 3 & 1 & 3 \\
16 & Pakpak Bharat & 1 & 1 & 1 \\
17 & Samosir & 7 & 1 & 1 \\
18 & Serdang Bedagai & 1 & 1 & 2 \\
19 & Batu Bara & 1 & 1 & 1 \\
20 & Paluta & 1 & 1 & 1 \\
21 & Padang Lawas & 1 & 1 & 8 \\
22 & Labusel & 1 & 1 & 1 \\
23 & Labura & 1 & 1 & 1 \\
\hline
\end{tabular}




\begin{tabular}{llccc}
\hline 24 & Nias Utara & 1 & 1 & 1 \\
25 & Nias Barat & 1 & 1 & 1 \\
26 & Tj. Balai & 1 & 1 & 1 \\
27 & P. Siantar & 1 & 1 & 1 \\
28 & Tebing Tinggi & 1 & 1 & 1 \\
29 & Medan & 1 & 1 & 1 \\
30 & Binjai & 1 & 1 & 1 \\
31 & P. Sidempuan & 1 & 1 & 1 \\
32 & Gn. Sitoli & 1 & 1 & 1 \\
& Jumlah & $\mathbf{9 6}$ & $\mathbf{4 5}$ & $\mathbf{8 6}$ \\
\hline
\end{tabular}

2. Setelah proses inisialisasi selesai masuk ke langkah kedua yaitu penentuan titik pusat (centroid) dari sample data yang akan dianalisa. Adapun centroid dari data tabel 4. yaitu:

a.Cluster ke-1 yaitu data ke 6 Toba Samosir $\{2,1,1\}$ sebagai $\mathrm{m} 1$

b. Cluster ke-2 yaitu data ke 13 Langkat $\{1,2,5\}$ sebagai $m 2$

c.Cluster ke-3 yaitu data ke $15 \mathrm{H}$. Hasundatan $\{2,1,1\}$ sebagai $\mathrm{m} 3$

3. Hitung jarak dengan centroid dengan menggunakan rumus sebagai berikut :

$D_{e}=\sqrt{(x i-s i)^{2}+(y i-t i)^{2}}$

Keterangan :

De $\quad=$ Euclidean Distance

$(x, y)=$ Banyaknya Objek

$(s, t) \quad=$ Koordinat Centroid

Pada langkah ini setiap data akan ditentukan centroid terdekatnya, dan data tersebut akan ditetapkan sebagai anggota kelompok yang terdekat dengan centroid.

a. Jarak V1 dengan $\mathrm{C} 1$

$$
\begin{aligned}
& D_{e}=\sqrt{(x i-s i)^{2}+(y i-t i)^{2}} \\
& D_{e}=\sqrt{(1-2)^{2}+(1-1)^{2}+(1-1)^{2}} \\
& D_{e}=1,000
\end{aligned}
$$

b. Jarak V1 dengan $\mathrm{C} 2$

$$
\begin{aligned}
& D_{e}=\sqrt{(x i-s i)^{2}+(y i-t i)^{2}} \\
& D_{e}=\sqrt{(1-1)^{2}+(1-2)^{2}+(1-5)^{2}} \\
& D_{e}=4,123
\end{aligned}
$$

c. Jarak V1 dengan $\mathrm{C} 3$

$$
\begin{aligned}
& D_{e}=\sqrt{(x i-s i)^{2}+(y i-t i)^{2}} \\
& D_{e}=\sqrt{(1-3)^{2}+(1-1)^{2}+(1-3)^{2}} \\
& D_{e}=2,828
\end{aligned}
$$

Tabel hasil perhitungan jarak selengkapnya antara masing-masing data dengan centroid :

Tabel 5. Hasil Perhitungan Iterasi 1

\begin{tabular}{clrrrrc}
\hline No. & Kabupaten/Kota & \multicolumn{1}{c}{ C1 } & \multicolumn{1}{c}{ C2 } & \multicolumn{1}{c}{ C2 } & Jarak Terdekat & Klaster \\
\hline 1 & Nias & 1,000 & 4,123 & 2,828 & 1,000 & 1 \\
2 & Madina & 3,317 & 1,000 & 2,449 & 1,000 & 2 \\
3 & Tap. Selatan & 13,928 & 14,071 & 12,369 & 12,369 & 3 \\
4 & Tap. Tengah & 3,162 & 1,414 & 2,236 & 1,414 & 2 \\
5 & Tap. Utara & 15,232 & 15,166 & 13,601 & 13,601 & 3 \\
6 & Toba Samosir & 0,000 & 4,243 & 2,236 & 0,000 & 1 \\
7 & Lab. Batu & 1,000 & 4,123 & 2,828 & 1,000 & 1 \\
8 & Asahan & 1,414 & 3,162 & 1,732 & 1,414 & 1 \\
9 & Simalungun & 5,099 & 6,782 & 4,123 & 4,123 & 3 \\
10 & Dairi & 8,602 & 8,124 & 6,708 & 6,708 & 3 \\
11 & Karo & 10,050 & 11,446 & 9,055 & 9,055 & 3 \\
12 & D. Serdang & 18,055 & 14,213 & 16,523 & 14,213 & 2 \\
13 & Langkat & 4,243 & 0,000 & 3,000 & 0,000 & 2 \\
14 & Nias Selatan & 1,000 & 4,123 & 2,828 & 1,000 & 1 \\
15 & H. Hasundatan & 2,236 & 3,000 & 0,000 & 0,000 & 3 \\
16 & Pakpak Bharat & 1,000 & 4,123 & 2,828 & 1,000 & 1 \\
17 & Samosir & 5,000 & 7,280 & 4,472 & 4,472 & 3 \\
18 & Serdang Bedagai & 1,414 & 3,162 & 2,236 & 1,414 & 1 \\
19 & Batu Bara & 1,000 & 4,123 & 2,828 & 1,000 & 1 \\
\hline
\end{tabular}


Variation) :

Pada langkah ini dihitung pula rasio antara besaran BCV (Between Cluster Variation) dengan WCV(Within Cluster

$\mathrm{M} 1=\{2,1,2\} \mathrm{M} 2=\{1,2,5\} \mathrm{M} 3=\{3,1,3\}$

$$
\begin{aligned}
d(m 1, m 2)= & \sqrt{(2-1)^{2}+(1-2)^{2}+(2-5)^{2}}=4,24 \\
d(m 1, m 3)= & \sqrt{(2-3)^{2}+(1-1)^{2}+(2-3)^{2}}=2,24 \\
d(m 2, m 3)= & \sqrt{(1-3)^{2}+(2-1)^{2}+(5-3)^{2}}=3,00 \\
B C V & =d(m 1, m 2)+d(m 1, m 3)+d(m 2, m 3) \\
& =4,24+2,24+3,00 \\
& =\mathbf{9 , 4 8}
\end{aligned}
$$

Hitung nilai WCV (Within Cluster Variation) dengan cara memangkatkan jarak terdekat cluster dan menjumlahkan setiap nilai WCV.

$$
\begin{aligned}
B C V & =1^{2}+1^{2}+12,369^{2}+1,414^{2}+13,601^{2}+\ldots .+1^{2} \\
& =738
\end{aligned}
$$

\begin{tabular}{|c|c|c|c|c|}
\hline \multirow{2}{*}{ No } & \multirow{2}{*}{ Kabupaten/Kota } & \multicolumn{3}{|c|}{ Cluster2 } \\
\hline & & $\mathrm{X} 1$ & $\mathrm{X} 2$ & X3 \\
\hline 2 & Madina & 1 & 2 & 4 \\
\hline
\end{tabular}

Sehingga besar rasio $=\mathrm{BCV} / \mathrm{WCV}=9,48 / 738=\mathbf{0 . 0 1 3}$

Karena langkah ini merupakan iterasi 1 maka lanjutkan kelangkah berikutnya. Pusat cluster baru ditentukan berdasarkan pengelompokkan anggota dari masing-masing cluster. Berikut ini merupakan pengelompokan pada pusat cluster baru :

Tabel 6. Hasil Kesimpulan Cluster 1 (Iterasi 1)

\begin{tabular}{clccc}
\hline \multirow{2}{*}{ No } & \multirow{2}{*}{ Kabupaten/Kota } & \multicolumn{3}{c}{ Cluster1 } \\
\cline { 3 - 5 } & & V1 & V2 & V3 \\
\hline 1 & Nias & 1 & 1 & 1 \\
6 & Toba Samosir & 2 & 1 & 1 \\
7 & Lab. Batu & 1 & 1 & 1 \\
8 & Asahan & 2 & 2 & 2 \\
14 & Nias Selatan & 1 & 1 & 1 \\
16 & Pakpak Bharat & 1 & 1 & 1 \\
18 & Serdang Bedagai & 1 & 1 & 2 \\
19 & Batu Bara & 1 & 1 & 1 \\
20 & Paluta & 1 & 1 & 1 \\
22 & Labusel & 1 & 1 & 1 \\
23 & Labura & 1 & 1 & 1 \\
24 & Nias Utara & 1 & 1 & 1 \\
25 & Nias Barat & 1 & 1 & 1 \\
26 & Tj. Balai & 1 & 1 & 1 \\
27 & P. Siantar & 1 & 1 & 1 \\
28 & Tebing Tinggi & 1 & 1 & 1 \\
29 & Medan & 1 & 1 & 1 \\
30 & Binjai & 1 & 1 & 1 \\
31 & P. Sidempuan & 1 & 1 & 1 \\
32 & Gn. Sitoli & 1 & 1 & 1 \\
& Rata - Rata & $\mathbf{1 , 1 0 0}$ & $\mathbf{1 , 0 5 0}$ & $\mathbf{1 , 1 0 0}$ \\
\hline
\end{tabular}

Tabel 7. Hasil Kesimpulan Cluster 2 (Iterasi 1) 


\begin{tabular}{clccc}
4 & Tap. Tengah & 1 & 1 & 4 \\
12 & D. Serdang & 1 & 11 & 16 \\
13 & Langkat & 1 & 2 & 5 \\
21 & Padang Lawas & 1 & 1 & 8 \\
& $\quad$ Rata - Rata & $\mathbf{1 , 0 0 0}$ & $\mathbf{3 , 4 0 0}$ & $\mathbf{7 , 4 0 0}$ \\
\hline
\end{tabular}

Tabel 8. Hasil Kesimpulan Cluster 3 (Iterasi 1)

\begin{tabular}{clccc}
\hline \multirow{2}{*}{ No } & \multirow{2}{*}{ Kabupaten/Kota } & \multicolumn{3}{c}{ Cluster3 } \\
\cline { 3 - 5 } & & $\mathrm{X} 1$ & $\mathrm{X} 2$ & $\mathrm{X} 3$ \\
\hline 3 & Tap. Selatan & 15 & 1 & 6 \\
5 & Tap. Utara & 16 & 1 & 7 \\
9 & Simalungun & 7 & 1 & 2 \\
10 & Dairi & 9 & 1 & 6 \\
11 & Karo & 12 & 1 & 2 \\
15 & H. Hasundatan & 3 & 1 & 3 \\
17 & Samosir & 7 & 1 & 1 \\
& $\quad$ Rata - rata & $\mathbf{9 , 8 5 7}$ & $\mathbf{1 , 0 0 0}$ & $\mathbf{3 , 8 5 7}$ \\
\hline
\end{tabular}

4. Lakukan perhitungan iterasi ke-2 dengan cara memasukan nilai dari centroid baru berdasarkan hasil rata-rata nilai setiap cluster. Adapun hasil rata-rata setiap cluster yang akan dipakai adalah sebagai berikut :

a.Cluster ke-1 yaitu $\{1,1001,0501,100\}$ sebagai $\mathrm{m} 1$

b. Cluster ke-2 yaitu $\{1,0003,4507,400\}$ sebagai $\mathrm{m} 2$ c.Cluster ke-3 yaitu $\{9,8571,0003,857\}$ sebagai m3

5. Hitung kembali jarak dengan centroid dengan menggunakan rumus sebagai berikut :

a.Jarak V1 dengan $\mathrm{C} 1$

$$
\begin{aligned}
& D_{e}=\sqrt{(x i-s i)^{2}+(y i-t i)^{2}} \\
& D_{e}=\sqrt{(1-1,100)^{2}+(1-1,050)^{2}+(1-1,100)^{2}} \\
& D_{e}=0,15
\end{aligned}
$$

b. Jarak V1 dengan C2

$$
\begin{aligned}
& D_{e}=\sqrt{(x i-s i)^{2}+(y i-t i)^{2}} \\
& D_{e}=\sqrt{(1-1,000)^{2}+(1-3,450)^{2}+(1-7,400)^{2}} \\
& D_{e}=6,84
\end{aligned}
$$

c.Jarak V1 dengan C3

$$
\begin{aligned}
& D_{e}=\sqrt{(x i-s i)^{2}+(y i-t i)^{2}} \\
& D_{e}=\sqrt{(1-9,857)^{2}+(1-1,000)^{2}+(1-3,857)^{2}} \\
& D_{e}=9,31
\end{aligned}
$$

Tabel hasil perhitungan jarak selengkapnya antara masing-masing data dengan centroid :

Tabel 8. Hasil Perhitungan Iterasi 2

\begin{tabular}{clrrrrc}
\hline No. & Kabupaten/Kota & \multicolumn{1}{c}{ M1 } & \multicolumn{1}{c}{ M2 } & M3 & Jarak Terdekat & Klaster \\
\hline 1 & Nias & 0,15 & 6,84 & 9,31 & 0,15 & 1 \\
2 & Madina & 3,05 & 3,68 & 8,91 & 3,05 & 1 \\
3 & Tap. Selatan & 14,74 & 14,27 & 5,57 & 5,57 & 3 \\
4 & Tap. Tengah & 2,90 & 4,16 & 8,86 & 2,90 & 1 \\
5 & Tap. Utara & 16,03 & 15,20 & 6,90 & 6,90 & 3 \\
6 & Toba Samosir & 0,91 & 6,91 & 8,36 & 0,91 & 1 \\
7 & Lab. Batu & 0,15 & 6,84 & 9,31 & 0,15 & 1 \\
8 & Asahan & 1,59 & 5,67 & 8,14 & 1,59 & 1 \\
9 & Simalungun & 5,97 & 8,42 & 3,41 & 3,41 & 3 \\
10 & Dairi & 9,30 & 8,47 & 2,31 & 2,31 & 3 \\
11 & Karo & 10,94 & 12,49 & 2,84 & 2,84 & 3 \\
12 & D. Serdang & 17,92 & 11,48 & 18,05 & 11,48 & 2 \\
13 & Langkat & 4,02 & 2,78 & 8,99 & 2,78 & 2 \\
14 & Nias Selatan & 0,15 & 6,84 & 9,31 & 0,15 & 1 \\
15 & H. Hasundatan & 2,69 & 5,40 & 6,91 & 2,69 & 1 \\
16 & Pakpak Bharat & 0,15 & 6,84 & 9,31 & 0,15 & 1 \\
17 & Samosir & 5,90 & 9,10 & 4,04 & 4,04 & 3 \\
18 & Serdang Bedagai & 0,91 & 5,91 & 9,05 & 0,91 & 1 \\
19 & Batu Bara & 0,15 & 6,84 & 9,31 & 0,15 & 1 \\
20 & Paluta & 0,15 & 6,84 & 9,31 & 0,15 & 1 \\
\hline
\end{tabular}




\begin{tabular}{lllllll}
\hline 21 & Padang Lawas & 6,90 & 2,47 & 9,78 & 2,47 & 2 \\
22 & Labusel & 0,15 & 6,84 & 9,31 & 0,15 & 1 \\
23 & Labura & 0,15 & 6,84 & 9,31 & 0,15 & 1 \\
24 & Nias Utara & 0,15 & 6,84 & 9,31 & 0,15 & 1 \\
25 & Nias Barat & 0,15 & 6,84 & 9,31 & 0,15 & 1 \\
26 & Tj. Balai & 0,15 & 6,84 & 9,31 & 0,15 & 1 \\
27 & P. Siantar & 0,15 & 6,84 & 9,31 & 0,15 & 1 \\
28 & Tebing Tinggi & 0,15 & 6,84 & 9,31 & 0,15 & 1 \\
29 & Medan & 0,15 & 6,84 & 9,31 & 0,15 & 1 \\
30 & Binjai & 0,15 & 6,84 & 9,31 & 0,15 & 1 \\
31 & P. Sidempuan & 0,15 & 6,84 & 9,31 & 0,15 & 1 \\
32 & Gn. Sitoli & 0,15 & 6,84 & 9,31 & 0,15 & 1 \\
\hline
\end{tabular}

Pada langkah dihitung kembali rasio antara besaran BCV (Between Cluster Variation) dengan WCV(Within Cluster Variation) pada iterasi yang ke-2 :

$$
\begin{aligned}
& \mathrm{M} 1=\{1,1001,0501,100\} \mathrm{M} 2=\{1,0003,4507,400\} \mathrm{M} 3=\{9,8571,0003,857\} \\
& \begin{aligned}
d(m 1, m 2) & =\sqrt{(1,100-1,000)^{2}+(1,050-3,450)^{2}+(1,100-7,400)^{2}}=6,72 \\
d(m 1, m 2) & =\sqrt{(1,100-9,857)^{2}+(1,050-1,000)^{2}+(1,100-3,857)^{2}}=9,18 \\
d(m 1, m 2) & =\sqrt{(1,000-9,857)^{2}+(3,450-1,000)^{2}+(9,857-3,857)^{2}}=9,84 \\
B C V & =d(m 1, m 2)+d(m 1, m 3)+d(m 2, m 3) \\
& =6,72+9,18+9,84 \\
& =\mathbf{2 5 , 7 4}
\end{aligned}
\end{aligned}
$$

Hitung nilai WCV (Within Cluster Variation) dengan cara memangkatkan jarak terdekat cluster dan menjumlahkan setiap nilai WCV.

$$
\begin{aligned}
B C V & =0,15^{2}+3,05^{2}+5,57^{2}+2,90^{2}+6,90^{2}+\ldots+0,15^{2} \\
& =\mathbf{2 9 5 , 0 4}
\end{aligned}
$$

Sehingga besar rasio $=\mathrm{BCV} / \mathrm{WCV}=25,74 / 295,04=\mathbf{0 . 0 8 7}$

Karena besarnya rasio iterasi ke-2 (0.087) masih lebih besar dari rasio iterasi ke-1 (0.013) maka dilanjutkan dengan cara melakukan iterasi ke 3. Pusat cluster baru ditentukan berdasarkan pengelompokkan anggota dari masing-masing cluster. Berikut ini merupakan pengelompokan pada pusat cluster baru :

Tabel 9. Hasil Kesimpulan Cluster 1 (Iterasi 2)

\begin{tabular}{clccc}
\hline \multirow{2}{*}{ No } & \multirow{2}{*}{ Kabupaten/Kota } & \multicolumn{3}{c}{ Cluster1 } \\
\cline { 3 - 5 } & & $\mathrm{X} 1$ & $\mathrm{X} 2$ & $\mathrm{X} 3$ \\
\hline 1 & Nias & 1 & 1 & 1 \\
2 & Madina & 1 & 1 & 4 \\
4 & Tap. Tengah & 2 & 1 & 4 \\
6 & Toba Samosir & 1 & 1 & 1 \\
7 & Lab. Batu & 2 & 2 & 2 \\
8 & Asahan & 1 & 1 & 1 \\
14 & Nias Selatan & 3 & 1 & 3 \\
15 & H. Hasundatan & 1 & 1 & 1 \\
16 & Pakpak Bharat & 1 & 1 & 2 \\
18 & Serdang Bedagai & 1 & 1 & 1 \\
19 & Batu Bara & 1 & 1 & 1 \\
20 & Paluta & 1 & 1 & 1 \\
22 & Labusel & 1 & 1 & 1 \\
23 & Labura & 1 & 1 & 1 \\
24 & Nias Utara & 1 & 1 & 1 \\
25 & Nias Barat & 1 & 1 & 1 \\
26 & Tj. Balai & 1 & 1 & 1 \\
27 & P. Siantar & 1 & 1 & 1 \\
28 & Tebing Tinggi & 1 & 1 & 1 \\
29 & Medan & 1 & 1 & 1 \\
30 & Binjai & 1 & 1 & 1 \\
31 & P. Sidempuan & 1 & 1 & 1 \\
32 & Gn. Sitoli & $\mathbf{1 7 4}$ & $\mathbf{1 0 8 7}$ & $\mathbf{1 3 5}$ \\
& & & & \\
\hline & & 1 & 1 & 1 \\
& & 1 & 1 & 1 \\
& & 1 & 1 \\
\hline
\end{tabular}


Tabel 10. Hasil Kesimpulan Cluster 2 (Iterasi 2)

\begin{tabular}{llccc}
\hline \multirow{2}{*}{ No } & \multirow{2}{*}{ Kabupaten/Kota } & \multicolumn{3}{c}{ Cluster2 } \\
\cline { 3 - 5 } & & $\mathrm{X} 1$ & $\mathrm{X} 2$ & $\mathrm{X} 3$ \\
\hline 12 & D. Serdang & 1 & 11 & 16 \\
13 & Langkat & 1 & 2 & 5 \\
21 & Padang Lawas & 1 & 1 & 8 \\
& & $\mathbf{1 , 0 0 0}$ & $\mathbf{4 , 6 6 7}$ & $\mathbf{9 , 6 6 7}$ \\
\hline
\end{tabular}

Tabel 11. Hasil Kesimpulan Cluster 3 (Iterasi 2)

\begin{tabular}{clrrr}
\hline \multirow{2}{*}{ No } & \multirow{2}{*}{ Kabupaten/Kota } & \multicolumn{3}{c}{ Cluster3 } \\
\cline { 3 - 5 } & & X1 & X2 & X3 \\
\hline 3 & Tap. Selatan & 15 & 1 & 6 \\
5 & Tap. Utara & 16 & 1 & 7 \\
9 & Simalungun & 7 & 1 & 2 \\
10 & Dairi & 9 & 1 & 6 \\
11 & Karo & 12 & 1 & 2 \\
17 & Samosir & 7 & 1 & 1 \\
& & $\mathbf{1 1 , 0 0 0}$ & $\mathbf{1 , 0 0 0}$ & $\mathbf{4 , 0 0 0}$ \\
\hline
\end{tabular}

6. Lakukan perhitungan iterasi ke-3 dengan cara memasukan nilai dari centroid baru berdasarkan hasil rata-rata nilai setiap cluster. Adapun hasil rata-rata setiap cluster yang akan dipakai adalah sebagai berikut :

a.Cluster ke-1 yaitu $\{1,1001,0501,100\}$ sebagai $\mathrm{m} 1$

b. Cluster ke-2 yaitu $\{1,0003,4507,400\}$ sebagai $\mathrm{m} 2$

c.Cluster ke-3 yaitu $\{9,857 \quad 1,0003,857\}$ sebagai $\mathrm{m} 3$

7. Hitung kembali jarak dengan centroid dengan menggunakan rumus sebagai berikut :

a.Jarak V1 dengan C1

$$
\begin{aligned}
& D_{e}=\sqrt{(x i-s i)^{2}+(y i-t i)^{2}} \\
& D_{e}=\sqrt{(1-1,100)^{2}+(1-1,050)^{2}+(1-1,100)^{2}} \\
& D_{e}=0,15
\end{aligned}
$$

b. Jarak V1 dengan C2

$$
\begin{aligned}
& D_{e}=\sqrt{(x i-s i)^{2}+(y i-t i)^{2}} \\
& D_{e}=\sqrt{(1-1,000)^{2}+(1-3,450)^{2}+(1-7,400)^{2}} \\
& D_{e}=6,84
\end{aligned}
$$

c. Jarak V1 dengan C3

$$
\begin{aligned}
& D_{e}=\sqrt{(x i-s i)^{2}+(y i-t i)^{2}} \\
& D_{e}=\sqrt{(1-9,857)^{2}+(1-1,000)^{2}+(1-3,857)^{2}} \\
& D_{e}=9,31
\end{aligned}
$$

Tabel hasil perhitungan jarak selengkapnya antara masing-masing data dengan centroid :

Tabel 12. Hasil Perhitungan Iterasi 3

\begin{tabular}{clrrrrc}
\hline No. & Kabupaten/Kota & \multicolumn{1}{c}{ M1 } & \multicolumn{1}{c}{ M2 } & \multicolumn{1}{c}{ M3 } & Jarak Terdekat & Klaster \\
\hline 1 & Nias & 0,15 & 6,84 & 9,31 & 0,15 & 1 \\
2 & Madina & 3,05 & 3,68 & 8,91 & 3,05 & 1 \\
3 & Tap. Selatan & 14,74 & 14,27 & 5,57 & 5,57 & 3 \\
4 & Tap. Tengah & 2,90 & 4,16 & 8,86 & 2,90 & 1 \\
5 & Tap. Utara & 16,03 & 15,20 & 6,90 & 6,90 & 3 \\
6 & Toba Samosir & 0,91 & 6,91 & 8,36 & 0,91 & 1 \\
7 & Lab. Batu & 0,15 & 6,84 & 9,31 & 0,15 & 1 \\
8 & Asahan & 1,59 & 5,67 & 8,14 & 1,59 & 1 \\
9 & Simalungun & 5,97 & 8,42 & 3,41 & 3,41 & 3 \\
10 & Dairi & 9,30 & 8,47 & 2,31 & 2,31 & 3 \\
11 & Karo & 10,94 & 12,49 & 2,84 & 2,84 & 3 \\
12 & D. Serdang & 17,92 & 11,48 & 18,05 & 11,48 & 2 \\
13 & Langkat & 4,02 & 2,78 & 8,99 & 2,78 & 2 \\
14 & Nias Selatan & 0,15 & 6,84 & 9,31 & 0,15 & 1 \\
15 & H. Hasundatan & 2,69 & 5,40 & 6,91 & 2,69 & 1 \\
16 & Pakpak Bharat & 0,15 & 6,84 & 9,31 & 0,15 & 1 \\
17 & Samosir & 5,90 & 9,10 & 4,04 & 4,04 & 3 \\
\hline
\end{tabular}




\begin{tabular}{lllllll}
\hline 18 & Serdang Bedagai & 0,91 & 5,91 & 9,05 & 0,91 & 1 \\
19 & Batu Bara & 0,15 & 6,84 & 9,31 & 0,15 & 1 \\
20 & Paluta & 0,15 & 6,84 & 9,31 & 0,15 & 1 \\
21 & Padang Lawas & 6,90 & 2,47 & 9,78 & 2,47 & 2 \\
22 & Labusel & 0,15 & 6,84 & 9,31 & 0,15 & 1 \\
23 & Labura & 0,15 & 6,84 & 9,31 & 0,15 & 1 \\
24 & Nias Utara & 0,15 & 6,84 & 9,31 & 0,15 & 1 \\
25 & Nias Barat & 0,15 & 6,84 & 9,31 & 0,15 & 1 \\
26 & Tj. Balai & 0,15 & 6,84 & 9,31 & 0,15 & 1 \\
27 & P. Siantar & 0,15 & 6,84 & 9,31 & 0,15 & 1 \\
28 & Tebing Tinggi & 0,15 & 6,84 & 9,31 & 0,15 & 1 \\
29 & Medan & 0,15 & 6,84 & 9,31 & 0,15 & 1 \\
30 & Binjai & 0,15 & 6,84 & 9,31 & 0,15 & 1 \\
31 & P. Sidempuan & 0,15 & 6,84 & 9,31 & 0,15 & 1 \\
32 & Gn. Sitoli & 0,15 & 6,84 & 9,31 & 0,15 & 1 \\
\hline
\end{tabular}

Pada langkah dihitung kembali rasio antara besaran BCV (Between Cluster Variation) dengan WCV(Within Cluster Variation) pada iterasi yang ke-3 :

$$
\begin{aligned}
& \mathrm{M} 1=\{1,1001,0501,100\} \mathrm{M} 2=\{1,0003,4507,400\} \mathrm{M} 3=\{9,8571,0003,857\} \\
& d(m 1, m 2)=\sqrt{(1,100-1,000)^{2}+(1,050-3,450)^{2}+(1,100-7,400)^{2}}=6,72 \\
& d(m 1, m 2)=\sqrt{(1,100-9,857)^{2}+(1,050-1,000)^{2}+(1,100-3,857)^{2}}=9,18 \\
& \begin{aligned}
d(m 1, m 2) & =\sqrt{(1,000-9,857)^{2}+(3,450-1,000)^{2}+(9,857-3,857)^{2}}=9,84 \\
B C V & =d(m 1, m 2)+d(m 1, m 3)+d(m 2, m 3) \\
& =6,72+9,18+9,84 \\
& =\mathbf{2 5}, \mathbf{7 4}
\end{aligned}
\end{aligned}
$$

Hitung nilai WCV (Within Cluster Variation) dengan cara memangkatkan jarak terdekat cluster dan menjumlahkan setiap nilai WCV.

$$
\begin{aligned}
B C V & =0,15^{2}+3,05^{2}+5,57^{2}+2,90^{2}+6,90^{2}+\ldots .+0,15^{2} \\
& =\mathbf{2 9 5 , 0 4}
\end{aligned}
$$

Sehingga besar rasio $=\mathrm{BCV} / \mathrm{WCV}=25,74 / 295,04=\mathbf{0 . 0 8 7}$

Karena besarnya rasio iterasi ke-3 (0.087) sama dengan rasio iterasi ke-2 0,087) maka perhitungan akan dihentikan. Berikut ini merupakan tabel kesimpulan yang dapat diambil dari iterasi ke-3

Tabel 13. Hasil Kesimpulan Cluster 1 (Iterasi 3)

\begin{tabular}{clccc}
\hline \multirow{2}{*}{ No } & \multirow{2}{*}{ Kabupaten/Kota } & \multicolumn{3}{c}{ Cluster1 } \\
\cline { 3 - 5 } & & X1 & X2 & X3 \\
\hline 1 & Nias & 1 & 1 & 1 \\
2 & Madina & 1 & 2 & 4 \\
3 & Tap. Tengah & 1 & 1 & 4 \\
4 & Toba Samosir & 2 & 1 & 1 \\
5 & Lab. Batu & 1 & 1 & 1 \\
6 & Asahan & 2 & 2 & 2 \\
7 & Nias Selatan & 1 & 1 & 1 \\
8 & H. Hasundatan & 3 & 1 & 3 \\
9 & Pakpak Bharat & 1 & 1 & 1 \\
10 & Serdang Bedagai & 1 & 1 & 2 \\
11 & Batu Bara & 1 & 1 & 1 \\
12 & Paluta & 1 & 1 & 1 \\
13 & Labusel & 1 & 1 & 1 \\
14 & Labura & 1 & 1 & 1 \\
15 & Nias Utara & 1 & 1 & 1 \\
16 & Nias Barat & 1 & 1 & 1 \\
17 & Tj. Balai & 1 & 1 & 1 \\
18 & P. Siantar & 1 & 1 & 1 \\
19 & Tebing Tinggi & 1 & 1 & 1 \\
20 & Medan & 1 & 1 & 1 \\
21 & Binjai & 1 & 1 & 1 \\
22 & P. Sidempuan & 1 & 1 & 1 \\
23 & Gn. Sitoli & 1 & 1 & 1 \\
& $\quad$ Rata-Rata & $\mathbf{1 , 1 7 4}$ & $\mathbf{1 , 0 8 7}$ & $\mathbf{1 , 4 3 5}$ \\
\hline
\end{tabular}


Tabel 14. Hasil Kesimpulan Cluster 2 (Iterasi 3)

\begin{tabular}{clccc}
\hline \multirow{2}{*}{ No } & \multirow{2}{*}{ Kabupaten/Kota } & \multicolumn{3}{c}{ Cluster2 } \\
\cline { 3 - 5 } & & $\mathrm{X} 1$ & $\mathrm{X} 2$ & $\mathrm{X} 3$ \\
\hline 1 & D. Serdang & 1 & 11 & 16 \\
2 & Langkat & 1 & 2 & 5 \\
3 & Padang Lawas & 1 & 1 & 8 \\
& Rata-Rata & $\mathbf{1 , 0 0 0}$ & $\mathbf{4 , 6 6 7}$ & $\mathbf{9 , 6 6 7}$ \\
\hline
\end{tabular}

Tabel 15. Hasil Kesimpulan Cluster 3 (Iterasi 3)

\begin{tabular}{|c|c|c|c|c|}
\hline \multirow{2}{*}{ No } & \multirow{2}{*}{ Kabupaten/Kota } & \multicolumn{3}{|c|}{ Cluster3 } \\
\hline & & $\mathrm{X} 1$ & $\mathrm{X} 2$ & X3 \\
\hline 1 & Tap. Selatan & 15 & 1 & 6 \\
\hline 2 & Tap. Utara & 16 & 1 & 7 \\
\hline 3 & Simalungun & 7 & 1 & 2 \\
\hline 4 & Dairi & 9 & 1 & 6 \\
\hline 5 & Karo & 12 & 1 & 2 \\
\hline 6 & Samosir & 7 & 1 & 1 \\
\hline & Rata-Rata & 11,000 & 1,000 & 4,000 \\
\hline
\end{tabular}

Berdasarkan hasil tabel setiap Cluster diatas dapat kesimpulan bahwa :

1. Kelompok daerah pada cluster 1 merupakan kelompok daerah yang potensi produksi buah alpukat, belimbing dan dukunya paling rendah.

2. Kelompok daerah pada cluster 2 merupakan kelompok daerah yang potensi produksi biah alpukat, belimbing dan dukunya menengah.

3. Kelompok daerah pada cluster 3 merupakan kelompok daerah yang potensi produksi buah alpukat, belimbing dan dukunya paling tinggi

Berdasarkan hasil kesimpulan diatas diharapkan pihak Dinas Tanaman Pangan dan Holtikultura Provinsi Sumatera Utara untuk dapat melakukan kebijakan-kebijakan yang dapat membantu meningkatkan produktivitas hasil buah sehingga bagi daerah- daerah yang termasuk dalam cluster yang kategori rendah dapat mengejar produktivitas seperti di daerah lain.

\subsection{Implementasi}

Di bawah ini merupakan tampilan dari implementasi sistem dari pada program pengelompokan potensi produksi buahbuahan di Provinsi Sumatera Utara Dengan Menerapkan K-Clustering (Studi Kasus : Dinas Tanaman Pangan Dan Holikultura ), sebagai berikut :

1. Tampilan Menu Utama

Tampilan halaman menu utama adalah sebagai berikut :

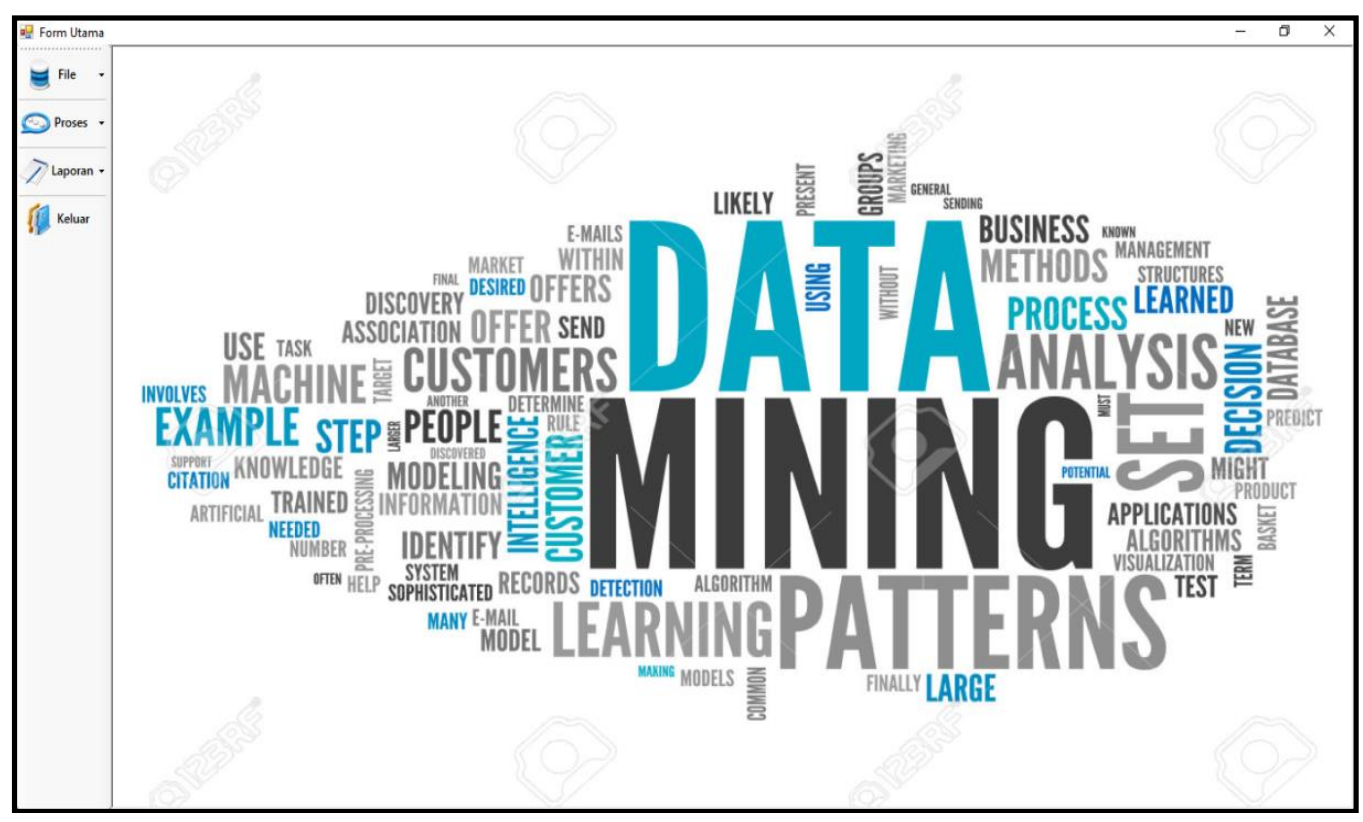

Gambar 1. Tampilan Menu Utama

2. Tampilan Form Data Produksi Buah

Di bawah ini merupakan tampilan form data produksi buah : 


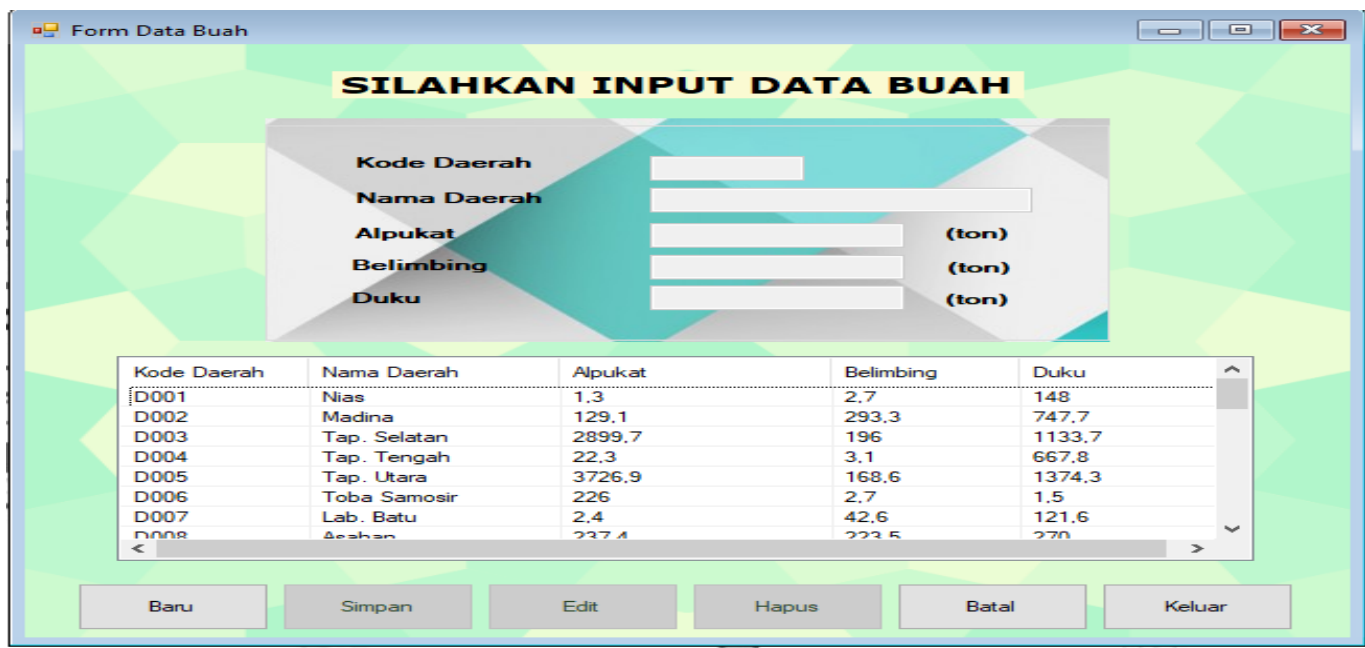

Gambar 2. Tampilan Form Input Data Produksi Buah

3. Tampilan Form Proses Inisialisasi Dan Pemilihan Centroid

Di bawah ini merupakan form inisialisasi dan pemilihan centroid :

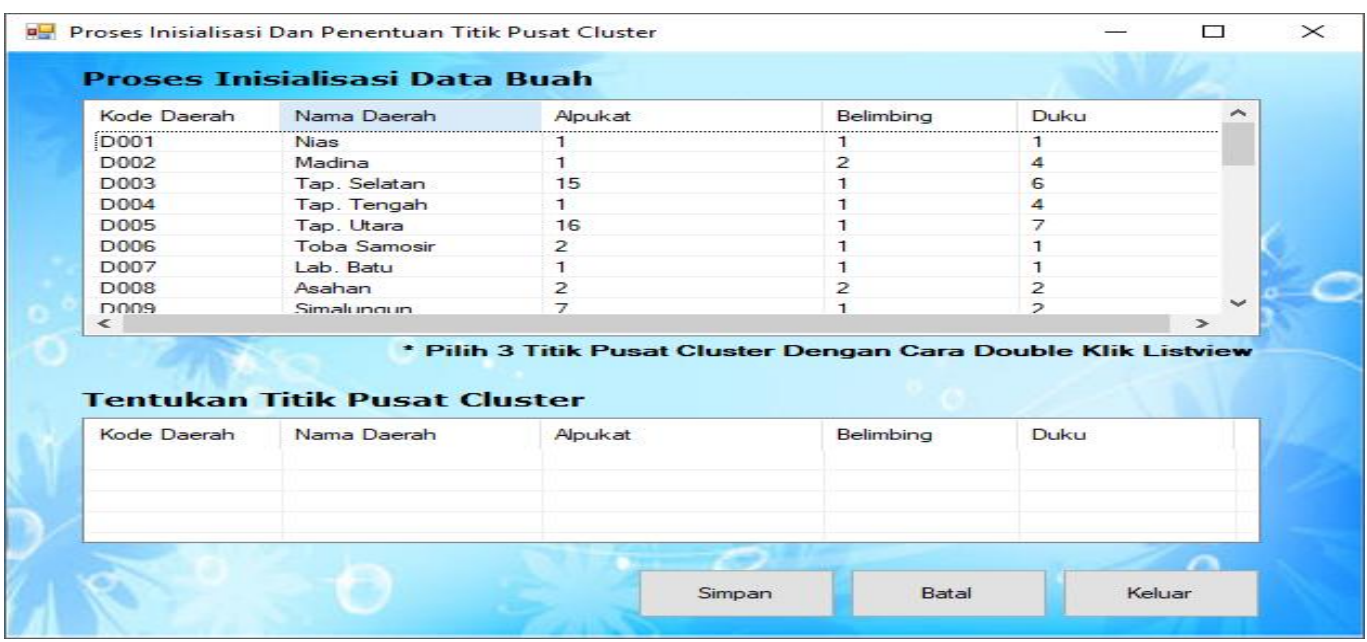

Gambar 3. Tampilan Form Inisialisasi Dan Pemilihan Centroid

4. Tampilan Form Proses Clustering

Di bawah ini merupakan tampilan dari form proses clustering:

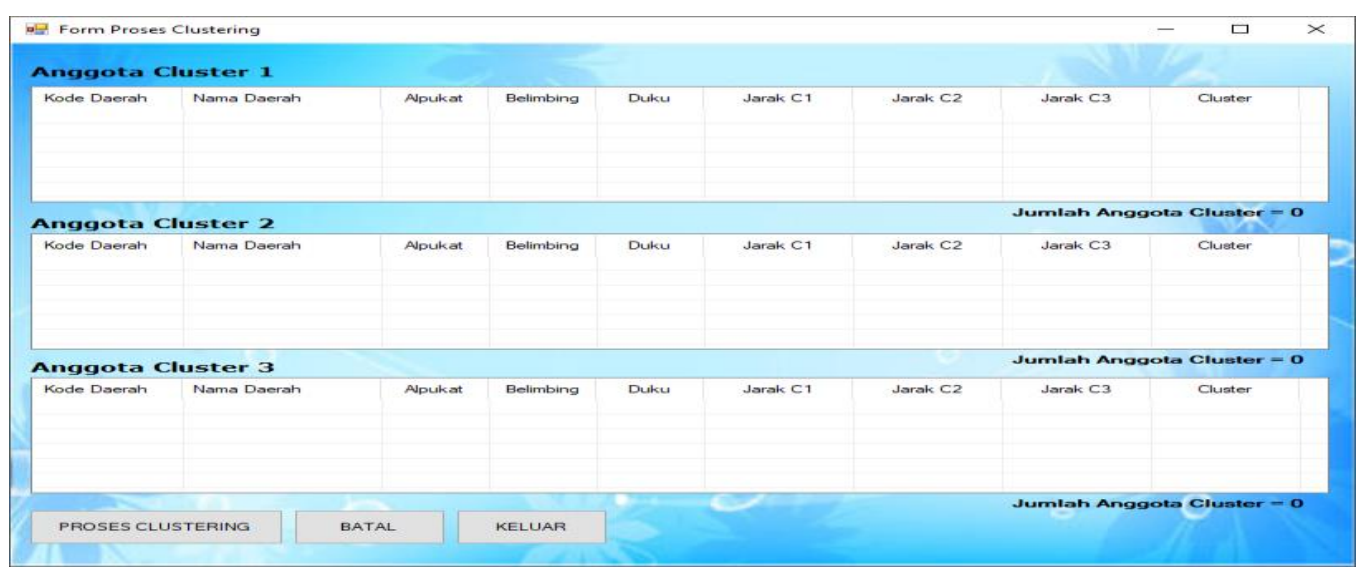

Gambar 4. Tampilan Form Proses Clustering

5. Tampilan Laporan Hasil Pengelompokan Potensi Buah

Laporan hasil pengelompokan potensi buah digunakan sebagai laporan yang kemudian nanti akan diarsipkan dan dipergunakan sebagai bahan pertimbangan dalam mengambil kebijakan di kemudian hari. 


\begin{tabular}{|c|c|c|c|c|c|}
\hline \multirow{2}{*}{\multicolumn{6}{|c|}{$\begin{array}{c}\text { PEMERINTAH PROVINSI SUMATE } \\
\text { DINAS TANAMAN PANGAN DAN H } \\
\text { J. Jenderal Besar Dr. Abdul Harris No.6 Gedung } \\
\text { Kode Pos : } 20143 \text {; Telp Fax, } 7863567-780 \\
\text { Website } \text { http///distan.sumutprov.go.id Email:distan pro } \\
\begin{array}{c}\text { Laporan Pengelompokan Potensi Buah } \\
\text { Provinsi Sumatera Utara }\end{array}\end{array}$}} \\
\hline & & & & & \\
\hline Kode Daerah & Nama Daerah & Jarak CI & Jarak C2 & Jarak C3 & Cluster \\
\hline D001 & Nias & 0,15 & 6,84 & 9,31 & 1 \\
\hline DOO2 & Madina & 3,05 & 3,68 & 8,91 & 1 \\
\hline DOO3 & Tap. Selatan & 14,74 & 14,27 & 5,57 & 3 \\
\hline DOO4 & Tap. Tengah & 2,90 & 4,16 & 8,86 & 1 \\
\hline Do05 & Tap. Utara & 16,03 & 15,20 & 6,90 & 3 \\
\hline D006 & Toba Samosir & 0,91 & 6,91 & 8,36 & 1 \\
\hline DO07 & Lab. Batu & 0,15 & 6,84 & 9,31 & 1 \\
\hline Doos & Asahan & 1,59 & 5,67 & 8,14 & 1 \\
\hline D009 & Simalungun & 5,97 & 8,42 & 3,41 & 3 \\
\hline D010 & Dairi & 9,30 & 8,47 & 2,31 & 3 \\
\hline D011 & Karo & 10,94 & 12,49 & 2,84 & 3 \\
\hline D012 & D. Serdang & 17,92 & 11,48 & 18,05 & 2 \\
\hline D013 & Langkat & 4,02 & 2,78 & 8,99 & 2 \\
\hline D014 & Nias Selatan & 0,15 & 6,84 & 9,31 & 1 \\
\hline
\end{tabular}

Gambar 5. Tampilan Laporan Hasil Pengelompokan Potensi Buah

6. Pengujian Sistem

Hasil pengujian sistem di dalam pengelompokan potensi produksi buah-buahan di Provinsi Sumatera Utara Dengan Menerapkan K-Clustering (Studi Kasus: Dinas Tanaman Pangan Dan Holikultura) menghasilkan hasil akhir sebagai berikut :

\begin{tabular}{|c|c|c|c|c|c|}
\hline \multicolumn{6}{|c|}{$\begin{array}{c}\text { PEMERINTAH PROVINSI SUMATERA UTARA } \\
\text { DINAS TANAMAAN PANGAN DAN HOLTIKULTURA } \\
\text { Л. Jenderal Besar Dr. Abdul Harris No.6 Gedung Johor Medan } \\
\text { Kode Pos : } 20143 \text {; TelpF Fax, } 7863567-78060633 \\
\text { Website :http//:distan.sumutprov.go.id Email:distan_propsu@yahoo.com }\end{array}$} \\
\hline \multicolumn{6}{|c|}{$\begin{array}{c}\text { Laporan Pengelompokan Potensi Buah } \\
\text { Provinsi Sumatera Utara }\end{array}$} \\
\hline Kode Daerah & Nama Daerah & Jarak Cl & Jarak C2 & Jarak C3 & Cluster \\
\hline D001 & Nias & 0,15 & 6,84 & 9,31 & 1 \\
\hline $\mathrm{D} 002$ & Madina & 3,05 & 3,68 & 8,91 & 1 \\
\hline D003 & Tap. Selatan & 14,74 & 14,27 & 5,57 & 3 \\
\hline D004 & Tap. Tengah & 2,90 & 4,16 & 8,86 & 1 \\
\hline D005 & Tap. Utara & 16,03 & 15,20 & 6,90 & 3 \\
\hline D006 & Toba Samosir & 0,91 & 6,91 & 8,36 & 1 \\
\hline DOO7 & Lab. Batu & 0,15 & 6,84 & 9,31 & 1 \\
\hline Doos & Asahan & 1,59 & 5,67 & 8,14 & 1 \\
\hline D009 & Simalungun & 5,97 & 8,42 & 3,41 & 3 \\
\hline D010 & Dairi & 9,30 & 8,47 & 2,31 & 3 \\
\hline D011 & Karo & 10,94 & 12,49 & 2,84 & 3 \\
\hline D012 & D. Serdang & 17,92 & 11,48 & 18,05 & 2 \\
\hline D013 & Langkat & 4,02 & 2,78 & 8,99 & 2 \\
\hline D014 & Nias Selatan & 0,15 & 6,84 & 9,31 & 1 \\
\hline
\end{tabular}

Gambar 6. Tampilan Output Program

\section{KESIMPULAN}

Adapun kesimpulan dari hasil penelitian, perancangan pada Aplikasi K-Means Clustering Pengelompokan potensi produksi buah-buahan di Provinsi Sumatera Utara yaitu :

1. Di Provinsi Sumatera setiap kabupaten/kota mempunyai hasil potensi produksi buah-buahan yang bervariasi jumlahnya dari data luas panen (Ha) dan produksi (ton). Data yang digunakan adalah data hasil potensi dari 30 kabupaten di sumatera utara dari tahun 2017 untuk data hasil produksi buah Alpukat, Duku, dan Belimbing.

2. Dari hasil analisa perhitungan data menggunakan algoritma k-means ini untuk memudahkan pemerintah untuk memperoleh informasi data pengelompokan potensi produksi buah-buahan di setiap kabupaten/kota diharapkan hasil 
dijadikan bahan pengambil kebijakan terkait peningkatan potensi produksi di kabupaten/kota dimasa mendatang, sehingga dapat mengoptimalkan program-program pemerintah di bidang pertanian..

\section{REFERENCES}

[1] Hendrayudi, 2011. Dasar-Dasar Pemrograman Microsoft Visual Basic 2008. Bandung: PT Sarana Tutorial Nurani Sejahtera.

[2] Hermawati, Fajar Astuti. 2013. Data Mining. Yogyakarta: Andi Offset.

[3] Kusrini., \& Emha T. L. 2009. Algoritma Data Mining. Yogyakarta: Andi Offset.

[4] Prasetyo, Eko. 2012. Data Mining: Konsep dan Aplikasi Menggunakan Matlab (edisi 1). Yogyakarta: Andi Offset.

[5] Rosa, A.S., \& M.Shalahuddin. 2015. Rekayasa Perangkat Lunak Terstruktur dan Berorientasi Objek. Bandung: Informatika.

[6] Sulindawati., \& Muhammad Fathoni. 2010. Pengantar Analisa Perancangan "Sistem”. Jurnal SAINTIKOM, 9(2), 1-19. 